\title{
STATUS KUALITAS AIR DAS CISANGGARUNG, JAWA BARAT
}

\author{
Rr Diah Nugraheni Setyowati \\ Teknik Lingkungan, Universitas Islam Negeri Sunan Ampel, Jl. Jend. A. Yani 117 Surabaya \\ Email: diahnugraheni@uinsby.ac.id
}

\begin{abstract}
ABSTRAK
Kualitas air merupakan salah satu komponen lingkungan yang sangat penting dan sebagai indikator sehatnya suatu daerah aliran sungai. Sejalan dengan perkembangan jumlah penduduk dan meningkatnya kegiatan masyarakat dan industri mengakibatkan perubahan fungsi lingkungan. Hal ini berdampak negatif terhadap kelestarian sumberdaya air yang diindikasikan dengan semakin meningkatnya daya rusak air. Degradasi yang terjadi di daerah aliran sungai berdampak pada perubahan aktifitas tata guna lahan dan ekosistem yang termasuk di dalamnya. Pemanfaatan fungsi sungai yang tercemar setara dengan kondisi kelangkaan air. Tingkat penurunan kualitas air akan mempengaruhi kelestarian sumberdaya air yang tersedia untuk penggunaan yang bermanfaat, dan pada gilirannya akan membatasi tata guna lahan produktif. DAS (daerah aliran sungai) Cisanggarung termasuk dalam wilayah Provinsi Jawa Barat dan Jawa Tengah, kabupaten yang termasuk dalam DAS Cisanggarung yaitu Kabupaten Cirebon dan Kuningan berada di Provinsi Jawa Barat, dan Kabupaten Brebes berada di Provinsi Jawa Tengah. Curah hujan yang terjadi di DAS Cisanggarung rata-rata sebesar $2.032 \mathrm{~mm}$. Potensi aliran rata-rata mencapai kapasitas sebesar 2,0 milyar meter kubik per tahun. Vegetasi yang ada sebagian besar berupa hutan, lahan pertanian, lahan perkebunan, lahan belukar dan lahan permukiman. Penelitian dilaksanakan di 6 Stasiun Pemantauan Kualitas Air Daerah Aliran Sungai Cisanggarung, yang secara administrasi masuk ke dalam wilayah kabupaten kuningan dan kabupaten Cirebon dengan tujuan untuk mengidentifikasi kualitas air sungai di DAS Cisanggarung, kemudian dapat diketahui status kualitas air di DAS Cisanggarung tersebut. Berdasarkan peruntukan air dan baku mutu air, maka diperoleh hasil bahwa Sungai Cisanggarung termasuk golongan B, C, D yaitu air yang memenuhi syarat untuk peruntukan golongan B (air baku air minum), golongan $\mathrm{C}$ (air untuk keperluan perikanan dan peternakan), golongan D (air yang digunakan untuk pertanian dan dapat digunakan untuk usaha perkotaan, industri dan pembangkit listrik tenaga air. Dari hasil dari analisa diperoleh faktor pembatas, adalah BOD, COD, kekeruhan, nitrat, ortho phospat, ammonium, amoniak, dan fecal coliform adalah melebihi baku mutu B, C, D sebagaimana tercantum dalam Surat Keputusan Gubernur Jawa Barat No. 58 Tahun 1998 tentang Peruntukan Air Dan Baku Mutu Air. Dan dari penelitian telah didapatkan hasil bahwa kadar BOD, COD, kekeruhan, amoniak, ammonium, nitrat, ortho phospat, dan kadar fecal coliform, telah melebihi baku mutu B, C, D yang diperbolehkan. Hal ini disebabkan karena pada daerah aliran sungai Cisanggarung banyak sekali kegiatan pertanian, perkebunan dan limbah rumah tangga dari pemukiman sehingga kualitas air sungai menjadi tidak baik.
\end{abstract}

Kata kunci: kualitas air, sumberdaya air, daerah aliran sungai

\section{PENDAHULUAN}

\section{Latar Belakang Masalah}

Masalah utama sumber daya air meliputi kuantitas air yang sudah tidak mampu memenuhi kebutuhan manusia yang terus meningkat dan kualitas air untuk keperluan domestik terus menurun khususnya untuk air minum. Sebagai sumber air minum masyarakat, maka harus memenuhi beberapa aspek yang meliputi kuantitas, kualitas dan kontinuitas (WHO, 2004). Kualitas air adalah istilah yang menggambarkan kesesuaian atau kecocokan air untuk penggunaan tertentu, misalnya: air minum, perikanan, pengairan/ irigasi, industri, rekreasi dan sebagainya. Peduli kualitas air adalah mengetahui kondisi air untuk menjamin keamanan dan kelestarian dalam penggunaannya. Kualitas air dapat diketahui dengan melakukan pengujian tertentu terhadap air tersebut. Pengujian yang biasa dilakukan adalah uji kimia, fisik, biologi, atau uji kenampakan (I-CLEAN, 2007). 
Kualitas air merupakan salah satu komponen lingkungan yang sangat penting dan sebagai indikator sehatnya suatu daerah aliran sungai. Sejalan dengan perkembangan jumlah penduduk dan meningkatnya kegiatan masyarakat dan industri mengakibatkan perubahan fungsi lingkungan. Hal ini berdampak negatif terhadap kelestarian sumberdaya air yang diindikasikan dengan semakin meningkatnya daya rusak air. Degradasi yang terjadi di daerah aliran sungai berdampak pada perubahan aktifitas tata guna lahan dan ekosistem yang termasuk di dalamnya. Pemanfaatan fungsi sungai yang tercemar setara dengan kondisi kelangkaan air. Tingkat penurunan kualitas air akan mempengaruhi kelestarian sumberdaya air yang tersedia untuk penggunaan yang bermanfaat, dan pada gilirannya akan membatasi tata guna lahan produktif.

Menurut Effendi (2003), kualitas air yaitu sifat air dan kandungan makhluk hidup, zat energi atau komponen lain di dalam air. Kualitas air dinyatakan dengan beberapa parameter yaitu parameter fisika seperti: Total Padatan Terlarut (TDS), Total Padatan Tersuspensi (TSS), dan sebagainya), parameter kimia (pH, Oksigen Terlarut (DO), BOD, kadar logam dan sebagainya), dan parameter biologi (Kandungan Bakteri Coliform, E-coli, keberadaan plankton, dan sebagainya). Pengukuran kualitas air dapat dilakukan dengan dua cara, yang pertama adalah pengukuran kualitas air dengan parameter fisika dan kimia, sedangkan yang kedua adalah pengukuran kualitas air dengan parameter biologi (Sihotang, 2006)

Daerah aliran sungai merupakan penghubung antara kawasan hulu dengan kawasan hilir, sehingga pencemaran di kawasan hulu akan berdampak pada kawasan hilir. DAS meliputi semua komponen lahan, air dan sumberdaya biotik yang merupakan suatu unit ekologi dan mempunyai keterkaitan antar komponen. Dalam suatu ekosistem DAS terjadi berbagai proses interaksi antar berbagai komponen yaitu tanah, air, vegetasi dan manusia. Sungai sebagai komponen utama DAS mempunyai potensi seimbang yang ditunjukkan oleh daya guna sungai tersebut, antara lain untuk pertanian dan energi. Namun demikian sungai juga dapat memberikan pengaruh negatif terhadap lingkungan, antara lain meluapnya air sungai dapat menyebabkan banjir, pembawa sedimentasi, pembawa limbah (Endiriyanti, 2011).

DAS Cisanggarung termasuk dalam wilayah Provinsi Jawa Barat dan Jawa Tengah, kabupaten yang termasuk dalam DAS Cisanggarung yaitu Kabupaten Cirebon dan Kuningan berada di Provinsi Jawa Barat, dan Kabupaten Brebes berada di Provinsi Jawa Tengah. Curah hujan yang terjadi di DAS Cisanggarung rata-rata sebesar $2.032 \mathrm{~mm}$. Potensi aliran rata-rata mencapai kapasitas sebesar 2,0 milyar meter kubik per tahun. Vegetasi yang ada sebagian besar berupa hutan, lahan pertanian, lahan perkebunan, lahan belukar dan lahan permukiman (Balai PSDA WS CimanukCisanggarung, 2008).

Kualitas air permukaan bergantung pada lingkungan sekitarnya sehingga diharapkan dapat mendukung ekosistem perairan dan memiliki nilai estetis. Kualitas air yang menurun disebabkan sumber pencemar sebagai akibat dari perubahan faktor-faktor lingkungan (Asdak, 2007). Pencemaran air adalah masuknya atau dimasukkannya makhluk hidup, zat, energi dan atau komponen lain ke dalam air oleh kegiatan manusia, sehingga kualitas air turun sampai ketingkat tertentu yang menyebabkan air tidak dapat berfungsi sesuai dengan peruntukannya. Beban pencemar adalah istilah yang dikaitkan dengan jumlah total bahan pencemar yang masuk ke dalam lingkungan baik secara langsung maupun tidak langsung sebagai hasil dari aktivitas manusia dalam memenuhi kebutuhan hidupnya pada areal tertentu dalam kurun waktu tertentu. Besarnya beban pencemar yang masuk ke perairan tergantung aktivitas manusia di sekitar daerah aliran sungai yang masuk perairan tersebut.Sumber pencemar terdiri atas 2 bentuk, yaitu:

1. Point sources, sumber pencemar yang membuang limbah cair ke dalam badan air pada lokasi tertentu.

2. Nonpoint sources, terdiri atas banyak sumber yang tersebar, baik ke badan airmaupun ke air tanah pada suatu daerah yang luas.

Pencemaran air dapat menjadi makin luas, tergantung dari kemampuan badan air penerima polutan untuk mengurangi kadar polutan secara alami. Apabila kemampuan badan air tersebut rendah dalam mereduksi kadar polutan, maka akan terjadi akumulasi polutan dalam air sehingga badan air akan menjadi trofik. Kategorisasi dari polutan air dengan melihat dampaknya terhadap sistem sungai sehingga dapat dibedakan menjadi tiga jenis polutan utama (Davie, 2008) yaitu:

- Senyawa beracun, yang menyebabkan gangguan pada aktivitas biologis lingkungan akuatik.

- Oksigen mempengaruhi keseimbangan senyawa, baik konsumsi oksigen atau menghambat transfer oksigen antara udara dan air. Hal ini juga termasuk polusi termal pada kondisi kelarutan oksigen dalam air akan berkurang dengan semakin meningkatnya temperatur.

- Padatan tersuspensi, partikel padat tersuspensi dalam air.

Kecepatan tiga kategori tersebut mengalami proses bergantung pada beban polutan yang telah ada di sungai, temperatur dan $\mathrm{pH}$ air, jumlah air yang mengalir di sungai dan potensi pencampuran sungai. Karakteristik aliran 
sungai yang pada gilirannya dipengaruhi oleh waktu, sifat aliran di sungai (misalnya bentuk dari kurva durasi aliran), serta kecepatan dan turbulensi aliran. Hal ini menunjukkan keterkaitan yang kuat antara kualitas air dan kuantitas air dalam sistem sungai (Davie, 2008).

\section{Maksud dan tujuan}

Mengidentifikasi kualitas air sungai di DAS (daerah aliran sungai) Cisanggarung, sehingga kemudian dapat diketahui status kualitas air di DAS Cisanggarung tersebut.

\section{Lokasi dan waktu penelitian}

Penelitian dilaksanakan di 6 (enam) Stasiun Pemantauan Kualitas Air Daerah Aliran Sungai Cisanggarung, yang secara administrasi masuk ke dalam wilayah kabupaten kuningan dan kabupaten Cirebon. Berikut ini adalah lokasi penelitian :

Tabel 1. Lokasi Penelitian

\begin{tabular}{|l|l|l|l|l|l|}
\hline No & $\begin{array}{l}\text { Kode } \\
\text { Stasiun }\end{array}$ & $\begin{array}{l}\text { Stasiun } \\
\text { Sampling }\end{array}$ & Desa & Kecamatan & Kabupaten \\
\hline 1 & CG 1 & Mata air Darmaloka & Darma & Darma & Kuningan \\
\hline 2 & CG 2 & Outlet Darma & Darma & Darma & Kuningan \\
\hline 3 & CG 3 & Jembatan Cibinuang & Cibinuang & Cibinuang & Kuningan \\
\hline 4 & CG 4 & Jembatan Bantarwangi & Purwasari & Garawangi & Kuningan \\
\hline 5 & CG 5 & Bendung Cikeusik & Cikeusik & Cidahu & Kuningan \\
\hline 6 & CG 6 & Jembatan Losari & Losari & Losari & Cirebon \\
\hline
\end{tabular}

Sumber : Balai PSDA WS Cimanuk-Cisanggarung (2008)

Penelitian ini dilaksanakan sekitar 6 bulan, dengan lokasi penentuan pemantauan air permukaan yang berasal dari daerah aliran sungai dengan penjelasan sebagai berikut :

a. Sumber alamiah, yaitu lokasi pada tempat yang belum terjadi atau masih sedikit pencemaran,

b. Sumber air tercemar, yaitu lokasi pada tempat yang telah mengalami perubahan (di hilir sumber pencemar),

c. Sumber air yang dimanfaatkan, yaitu lokasi pada tempat penyadapan pemanfaatan sumber air tersebut.

Tabel 2. Sumber Pencemar Sungai

\begin{tabular}{|l|l|l|l|}
\hline No & $\begin{array}{l}\text { Kode } \\
\text { Stasiun }\end{array}$ & Stasiun Sampling & Sumber Pencemar \\
\hline 1 & CG 1 & Mata air Darmaloka & - \\
\hline 2 & CG 2 & Outlet Darma & perikanan, desa, pertanian \\
\hline 3 & CG 3 & Jembatan Cibinuang & desa, pertanian \\
\hline 4 & CG 4 & Jembatan Bantarwangi & perkotaan, pertanian \\
\hline 5 & CG 5 & Bendung Cikeusik & desa, pertanian \\
\hline 6 & CG 6 & Jembatan Losari & desa, pertanian \\
\hline
\end{tabular}

Sumber : Balai PSDA WS Cimanuk-Cisanggarung (2008) 


\section{METODE PENELITIAN}

Metodologi penelitian merupakan langkah-langkah atau metode yang dilakukan dalam penelitian suatu masalah, kasus, gejala, fenomena atau lainnya dengan jalan ilmiah untuk menghasilkan suatu jawaban yang rasional. Metode yang digunakan dalam penelitian ini ialah metode deskriptif eksplanatif yaitu metode yang dilakukan dengan pendekatan studi kasus. Studi kasus dilaksanakan untuk memperoleh data-data dari fenomena yang berlangsung dan mencari keterangan-keterangan secara faktual dari suatu kelompok, sehingga kesimpulan yang diperoleh dapat dipergunakan untuk menggambarkan kasus-kasus lain yang sama tipenya (Arikunto, 2006).

Menurut Haslam (1995), kualitas air secara umum mengacu pada kandungan pollutan yang terkandung dalam air dan kaitannya untuk menunjang kehidupan ekosistem yang ada di dalamnya. Parameter fisika, kimia, biologi yang digunakan pada penelitian ini dalam menentukan kualitas air sungai DAS Cisanggarung adalah sebagai berikut :

a. Temperatur/ Suhu Air

Kenaikan suhu menyebabkan terjadinya peningkatan konsumsi oksigen, namun di lain pihak juga mengakibatkan turunnya oksigen dalam air (Effendi, 2003). Kenaikan suhu mengakibatkan: turunnya oksigen terlarut, kecepatan reaksi kimia meningkat, sehingga mahluk hidup di dalamnya akan mati.

b. Daya Hantar Listrik (DHL)

Merupakan taraf kegaraman air. Perairan alami memiliki DHL 0,02 - 1,50 $\mu \mathrm{mhos} / \mathrm{cm}$.

c. Derajat Keasaman $(\mathrm{pH})$

Merupakan gambaran jumlah atau aktivitas ion hidrogen dalam perairan. Perairan yang baik mempunyai nilai $\mathrm{pH}$ $=7$ (netral).

d. Padatan Terlarut Total (Total Dissolved Solid/ TDS)

TDS cenderung mengalami peningkatan dari hulu ke hilir, karena terdapat pemukiman penduduk di sekitar bagian tengah dan hilir. Baku mutu air menurut PP No 82 tahun 2001, kadar maksimum TDS yang diperbolehkan dalam penggunaan air golongan I, II, III adalah 1000 mg/l, sedangkan untuk golongan IV sebesar 2000 mg/l.

e. Dissolved Oxygen (DO)

Jeffries dan Mills (1996) membagi status kualitas air berdasarkan kadar oksigen terlarut, sebagaimana dapat dilihat pada tabel 3 .

Tabel 3. Status Kualitas Air berdasarkan Kadar Oksigen Terlarut

\begin{tabular}{|l|c|l|}
\hline No & Kadar oksigen terlarut & Status kualitas air \\
\hline 1 & $>6,5 \mathrm{mg} / \mathrm{l}$ & Tidak tercemar - tercemar sangat ringan \\
\hline 2 & $4,5-6,4 \mathrm{mg} / \mathrm{l}$ & Tercemar ringan \\
\hline 3 & $2,0-4,4 \mathrm{mg} / \mathrm{l}$ & Tercemar sedang \\
\hline 4 & $<2,0 \mathrm{mg} / \mathrm{l}$ & Tercemar berat \\
\hline
\end{tabular}

f. Biological Oxygen Demand (BOD)

Lee (1998) mengklasifikasikan besarnya tingkat pencemaran air untuk organisme akuatik berdasarkan kandungan BOD menjadi 4 golongan, sebagaimana tabel 4 berikut ini.

Tabel 4. Status Kualitas Air berdasarkan BOD

\begin{tabular}{|l|c|l|}
\hline No & Nilai BOD & Status kualitas air \\
\hline 1 & $<3,0 \mathrm{ppm}$ & Tidak tercemar \\
\hline 2 & $3,0-5,0 \mathrm{ppm}$ & Tercemar ringan \\
\hline 3 & $5,1-14,9 \mathrm{ppm}$ & Tercemar sedang \\
\hline 4 & $>15,0 \mathrm{ppm}$ & Tercemar berat \\
\hline
\end{tabular}

g. Chemycal Oxygen Demand (COD)

Merupakan jumlah oksigen yang dibutuhkan dalam proses oksidasi kimia.

h. Amoniak dan Amonium

Kadar amoniak dan amonium yang tinggi pada air sungai selalu menunjukkan adanya pencemaran. 
i. Nitrat

Merupakan senyawa toksik yang dapat mematikan organisme air. Konsentrasi nitrat yang tinggi menyebabkan pencemaran. Schmidt (1978) dalam Wardoyo (1989) membagi status kualitas air berdasarkan nilai nitrat, sebagaimana dapat dilihat pada tabel 5 berikut ini.

Tabel 5. Status Kualitas Air berdasarkan Kandungan Nitrat

\begin{tabular}{|l|l|l|}
\hline No & Kadar Nitrat & Status Kualitas Air \\
\hline 1 & $<0,003 \mathrm{mg} / \mathrm{l}$ & Tidak tercemar - tercemar sangat ringan \\
\hline 2 & $0,003-0,014 \mathrm{mg} / \mathrm{l}$ & Tercemar sedang \\
\hline 3 & $>0,014 \mathrm{mg} / \mathrm{l}$ & Tercemar berat \\
\hline
\end{tabular}

j. Orto Phospat

Merupakan bentuk fosfat yang dapat dimanfaatkan secara langsung oleh tumbuhan akuatik, kandungan fosfat yang terdapat di perairan umum tidak lebih dari $0,2 \mathrm{mg} / \mathrm{l}$.

k. Kekeruhan (Turbidity)

Merupakan suatu ukuran yang menyatakan seberapa jauh cahaya dapat menembus air, dimana cahaya yang menembus air akan mengalami pemantulan oleh bahan-bahan tersuspensi dan bahan koloid (Jeffries dan Mills, 1996). Turbiditas penting bagi kualitas air, terutama berkenaan dengan estetika, daya filter dan disinfeksi.

1. Bakteri Coliform

BMFT Project 02 WT 8851 (1993) menerangkan adanya organisme coliform dalam air dianggap sebagai bukti kontaminasi karena organisme ini asal usulnya dari dalam pencernaan manusia atau hewan berdarah panas lainnya.

\section{HASIL DAN PEMBAHASAN}

Berdasarkan data series yang diperoleh dari tahun 2008-2013, berikut ini diperoleh hasil penelitian sebagai berikut:

a. Temperatur / Suhu Air

Kenaikan suhu menyebabkan terjadinya peningkatan konsumsi oksigen, namun di lain pihak juga mengakibatkan turunnya oksigen dalam air (Effendi, 2003). Kenaikan suhu mengakibatkan: turunnya oksigen terlarut, kecepatan reaksi kimia meningkat, sehingga mahluk hidup di dalamnya akan mati. Berdasarkan data series yang diperoleh dari tahun 2008-2013, menunjukkan bahwa temperatur air di DAS Cisanggarung berkisar antara $24,5^{\circ} \mathrm{C}-$ 34, $3^{\circ}$ C. Berdasarkan Surat Keputusan Gubernur Jawa Barat No. 58 Tahun 1998 tentang Peruntukan Air Dan Baku Mutu Air golongan B, C, D untuk parameter temperatur air di daerah hulu DAS Cisanggarung (CG-1) lebih rendah dibandingkan temperature di daerah hilir (CG-6), hal ini disebabkan karena adanya perbedaan ketinggian elevasi permukaan tanah di DAS Cisanggarung. Di samping itu, penggunaan lahan di lokasi hilir banyak didominasi oleh lahan perkebunan, pertanian dan pemukiman, sehingga secara tidak langsung mempengaruhi temperatur air sungai.

b. Daya Hantar Listrik (DHL)

Merupakan taraf kegaraman air. Perairan alami memiliki DHL $0,02-1,50 \mu \mathrm{mhos} / \mathrm{cm}$. Melihat hasil pengujian kualitas air pada Stasiun Pemantauan Kualitas Air DAS Cisanggarung, Dilihat dari parameter kualitas air, nilai DHL daerah hulu DAS Cisanggarung (CG-1) lebih rendah dibandingkan temperature di daerah hilir (CG-6), karena di bagian hilir sungai banyak mengandung kadar zat padat terlarut dalam air. Berdasarkan hasil analisis kualitas air dari 6 stasiun pemantauan kualitas air DAS Cisanggarung, menunjukkan bahwa DHL berkisar antara $101 \mu \mathrm{mhos} / \mathrm{cm}-980 \mu \mathrm{mhos} / \mathrm{cm}$ yang artinya masih dibawah ambang batas nilai DHL sebesar $2.250 \mu \mathrm{mhos} / \mathrm{cm}$ (Berdasarkan Surat Keputusan Gubernur Jawa Barat No. 58 Tahun 1998 tentang Peruntukan Air Dan Baku Mutu Air). Dari hasil penelitian tersebut, dapat disimpulkan bahwa air DAS Cisanggarung dapat digunakan sebagai air baku untuk air minum, pertanian maupun perikanan.

c. Derajat Keasaman $(\mathrm{pH})$

Merupakan gambaran jumlah atau aktivitas ion hidrogen dalam perairan. Perairan yang baik mempunyai nilai $\mathrm{pH}$ $=7$ (netral). Dari pemantauan pada Stasiun Pemantauan Kualitas Air DAS Cisanggarung menunjukkan bahwa derajat keasaman air $(\mathrm{pH})$ berkisar antara 6,81 -7,79. Artinya dari hasil analisis tersebut, derajat keasaman air di 
daerah tersebut masih memenuhi syarat sebagai air minum dari batas yang diperbolehkan yaitu 6-9 (Berdasarkan Surat Keputusan Gubernur Jawa Barat No. 58 Tahun 1998 tentang Peruntukan Air Dan Baku Mutu Air).

d. Padatan Terlarut Total (Total Dissolved Solid/ TDS)

TDS cenderung mengalami peningkatan dari hulu ke hilir, karena terdapat pemukiman penduduk di sekitar bagian tengah dan hilir. Baku mutu air menurut PP No 82 tahun 2001, kadar maksimum TDS yang diperbolehkan dalam penggunaan air golongan I, II, III adalah $1000 \mathrm{mg} / \mathrm{l}$, sedangkan untuk golongan IV sebesar $2000 \mathrm{mg} / \mathrm{l}$. Berdasarkan pemantauan air dari 6 stasiun pemantauan kualitas air DAS Cisanggarung menunjukkan bahwa daerah hulu DAS Cisanggarung (CG-1) lebih rendah dibandingkan temperatur di daerah hilir (CG-6). Pada stasiun tersebut diperoleh nilai tds maksimal $942 \mathrm{mg} / \mathrm{l}$, artinyamasih di bawah ambang batas nilai total padatan terlarut (TDS) yaitu sebesar 1000 mg/l (Berdasarkan Surat Keputusan Gubernur Jawa Barat No. 58 Tahun 1998 tentang Peruntukan Air Dan Baku Mutu Air). Dari hasil penelitian tersebut, dapat disimpulkan bahwa air DAS Cisanggarung dapat digunakan sebagai air baku untuk air minum, pertanian maupun perikanan.

e. Dissolved Oxygen (DO)

Berdasarkan hasil analisis kualitas air dari 6 stasiun pemantauan kualitas air DAS Cisanggarung, menunjukkan bahwa DO berkisar antara 3,63 mg/l - 13,11 mg/l. Parameter kualitas air tersebut masih di bawah ambang batas minimal yang dipersyaratkan oksigen terlarut (DO) yaitu sebesar > $3 \mathrm{mg} / \mathrm{l}$ (Berdasarkan Surat Keputusan Gubernur Jawa Barat No. 58 Tahun 1998 tentang Peruntukan Air Dan Baku Mutu Air). Dari hasil penelitian tersebut, dapat disimpulkan bahwa air DAS Cisanggarung dapat digunakan sebagai air baku untuk air minum, pertanian maupun perikanan.

f. Biological Oxygen Demand (BOD)

Berdasarkan hasil analisis kualitas air dari 6 stasiun pemantauan kualitas air DAS Cisanggarung, menunjukkan bahwa BOD berkisar antara 1,28 mg/l - 46,00 mg/l. Dilihat dari parameter kualitas air nilai BOD sebesar $6 \mathrm{mg} / \mathrm{l}$ (Berdasarkan Surat Keputusan Gubernur Jawa Barat No. 58 Tahun 1998 tentang Peruntukan Air Dan Baku Mutu Air). Hal ini menunjukkan bahwa bila dilihat dari parameter BOD air DAS Cisanggarung tidak memenuhi baku mutu golongan B, C, D.

g. Chemycal Oxygen Demand (COD)

Merupakan jumlah oksigen yang dibutuhkan dalam proses oksidasi kimia. Berdasarkan hasil analisis kualitas air dari 6 stasiun pemantauan kualitas air DAS Cisanggarung, menunjukkan bahwa COD berkisar antara 2,23 mg/l $115,17 \mathrm{mg} / \mathrm{l}$. Dilihat dari parameter kualitas air nilai COD sudah diatas ambang batas minimal yang dipersyaratkan COD, sebesar 10 mg/l (Berdasarkan Surat Keputusan Gubernur Jawa Barat No. 58 Tahun 1998 tentang Peruntukan Air Dan Baku Mutu Air). Hal ini menunjukkan bahwa dilihat dari parameter COD air DAS Cisanggarung kurang baik digunakan sebagai air baku untuk air minum, air pertanian maupun perikanan.

h. Amoniak dan Amonium

Berdasarkan hasil analisis kualitas air dari 6 stasiun pemantauan kualitas air DAS Cisanggarung, menunjukkan bahwa kadar Amoniak berkisar antara 0,02 mg/l - 1,25 mg/l. Dilihat dari parameter kualitas air nilai amoniak sudah diatas ambang batas minimal yang dipersyaratkan yaitu sebesar 0,50 mg/l (Berdasarkan Surat Keputusan Gubernur Jawa Barat No. 58 Tahun 1998 tentang Peruntukan Air Dan Baku Mutu Air). Hal ini menunjukkan bahwa dilihat dari parameter kadar amoniak air DAS Cisanggarung kurang baik digunakan sebagai air baku untuk air minum, air pertanian maupun perikanan.

Berdasarkan hasil analisis kualitas air dari 6 stasiun pemantauan kualitas air DAS Cisanggarung, menunjukkan bahwa kadar Ammonium berkisar antara 0,02 mg/l - 1,11 mg/l. Dilihat dari parameter kualitas air nilai Ammonium sudah diatas ambang batas minimal yang dipersyaratkan yaitu sebesar 0,50 mg/l (Berdasarkan Surat Keputusan Gubernur Jawa Barat No. 58 Tahun 1998 tentang Peruntukan Air Dan Baku Mutu Air). Hal ini menunjukkan bahwa dilihat dari parameter kadar Ammonium air DAS Cisanggarung kurang baik digunakan sebagai air baku untuk air minum, air pertanian maupun perikanan.

i. Nitrat

Merupakan senyawa toksik yang dapat mematikan organisme air. Konsentrasi nitrat yang tinggi menyebabkan pencemaran. Berdasarkan hasil analisis kualitas air dari 6 stasiun pemantauan kualitas air DAS Cisanggarung, menunjukkan bahwa Nitrat berkisar antara 0,03 - 6,99. Dilihat dari parameter kualitas air nilai nitrat masih dibawah ambang batas minimal yang dipersyaratkan nitrat, sebesar $10 \mathrm{mg} / \mathrm{l}$ (Berdasarkan Surat Keputusan Gubernur Jawa Barat No. 58 Tahun 1998 tentang Peruntukan Air Dan Baku Mutu Air). Hal ini menunjukkan bahwa dilihat dari parameter nitrat air DAS Cisanggarung masih dapat digunakan sebagai air baku untuk air minum, air pertanian maupun perikanan. 
j. Orto Phospat

Merupakan bentuk fosfat yang dapat dimanfaatkan secara langsung oleh tumbuhan akuatik, kandungan fosfat yang terdapat di perairan umum tidak lebih dari $0,2 \mathrm{mg} / \mathrm{l}$. Berdasarkan hasil analisis kualitas air dari 6 stasiun pemantauan kualitas air DAS Cisanggarung, menunjukkan bahwa ortho phospat berkisar antara 0,04-3,22. Dilihat dari parameter kualitas air nilai ortho phospat sudah melebihi ambang batas minimal yang dipersyaratkan ortho phospat sebesar 0,20 mg/l (Berdasarkan Surat Keputusan Gubernur Jawa Barat No. 58 Tahun 1998 tentang Peruntukan Air Dan Baku Mutu Air). Hal ini menunjukkan bahwa dilihat dari parameter ortho phospat air DAS Cisanggarung kurang baik untuk digunakan sebagai air baku untuk air minum, air pertanian maupun perikanan.

k. Kekeruhan (Turbidity)

Merupakan suatu ukuran yang menyatakan seberapa jauh cahaya dapat menembus air, dimana cahaya yang menembus air akan mengalami pemantulan oleh bahan-bahan tersuspensi dan bahan koloid (Jeffries dan Mills, 1996). Turbiditas penting bagi kualitas air, terutama berkenaan dengan estetika, daya filter dan disinfeksi. Berdasarkan hasil analisis kualitas air dari 6 stasiun pemantauan kualitas air DAS Cisanggarung, menunjukkan bahwa kekeruhan air berkisar antara 1,05 NTU - 1.770 NTU. Dilihat dari parameter nilai kekeruhan air sudah melebihi ambang batas minimal yang dipersyaratkan yaitu 5 NTU (Berdasarkan Surat Keputusan Gubernur Jawa Barat No. 58 Tahun 1998 tentang Peruntukan Air Dan Baku Mutu Air). Hal ini menunjukkan perlunya ada perlakuan khusus untuk mengurangi kadar kekeruhan tersebut.

1. Bakteri Coliform/ Fecal Coliform

BMFT Project 02 WT 8851 (1993) menerangkan adanya fecal coliform dalam air dianggap sebagai bukti kontaminasi karena organisme ini asal usulnya dari dalam pencernaan manusia atau hewan berdarah panas lainnya. Berdasarkan hasil analisis laboratorium kualitas air dari 6 stasiun pemantauan kualitas air DAS Cisanggarung, menunjukkan bahwa fecal coliform berkisar antara $15.000-950.000 \mathrm{MPN} / 100 \mathrm{ml}$. Dilihat dari parameter kualitas air kandungan fecal coliform sudah melebihi ambang batas minimal yang dipersyaratkan kandungan fecal coliform sebesar 2000 MPN/100ml (Berdasarkan Surat Keputusan Gubernur Jawa Barat No. 58 Tahun 1998 tentang Peruntukan Air Dan Baku Mutu Air). Hal ini menunjukkan bahwa dilihat dari parameter kandungan fecal coliform air DAS Cisanggarung tidak memenuhi baku mutu golongan B, C, D yaitu air baku untuk air minum, air pertanian, peternakan maupun perikanan.

\section{KESIMPULAN}

Berdasarkan Surat Keputusan Gubernur Jawa Barat No. 58 Tahun 1998 tentang Peruntukan Air Dan Baku Mutu Air, menentukan baku mutu air ke dalam 6 golongan :

a. Golongan A, adalah air yang dapat digunakan sebagai air minum langsung tanpa pengolahan terlebih dahulu

b. Golongan B, adalah air yang dapat digunakan sebagai air baku air minum

c. Golongan $\mathrm{C}$, adalah air yang dapat digunakan untuk keperluan perikanan dan pertanian

d. Golongan D, adalah air yang dapat digunakan untuk pertanian dan dapat dimanfaatkan untuk usaha perkotaan, industri dan pembangkit listrik

e. Golongan B, C, D adalah air yang memenuhi peruntukkan golongan B, C, D

f. Golongan C, D adalah air yang memenuhi peruntukkan golongan C dan D

Berdasarkan peruntukan air dan baku mutu air, maka diperoleh hasil bahwa Sungai Cisanggarung termasuk golongan B, C, D yaitu air yang memenuhi syarat untuk peruntukan golongan B (air baku air minum), golongan C (air untuk keperluan perikanan dan peternakan), golongan D (air yang digunakan untuk pertanian dan dapat digunakan untuk usaha perkotaan, industri dan pembangkit listrik tenaga air. Dari hasil dari analisa diperoleh faktor pembatas, adalah BOD, COD, kekeruhan, nitrat, ortho phospat, ammonium, amoniak, dan fecal coliform adalah melebihi baku mutu B, C, D sebagaimana tercantum dalam Surat Keputusan Gubernur Jawa Barat No. 58 Tahun 1998 tentang Peruntukan Air Dan Baku Mutu Air.

Tentang Peruntukan Air Dan Baku Mutu Air, yaitu baku mutu untuk parameter BOD sebesar 6 mg/l, COD sebesar 10 $\mathrm{mg} / \mathrm{l}$, Kekeruhan $5 \mathrm{NTU}$, nilai Amoniak yang dipersyaratkan yaitu sebesar 0,50 mg/l, nilai Ammonium yang dipersyaratkan yaitu sebesar $0,50 \mathrm{mg} / \mathrm{l}$, nilai Nitrat yang dipersyaratkan sebesar $10 \mathrm{mg} / \mathrm{l}$, Ortho Phospat sebesar 0,20 $\mathrm{mg} / \mathrm{l}$, kandungan fecal coliform sebesar $2000 \mathrm{MPN} / 100 \mathrm{ml}$. Untuk lebih jelasnya kualitas air daerah aliran sungai Cisanggarung, dapat dilihat pada tabel 6 berikut ini. 
Tabel 6. Status Kualitas Air DAS Cisanggarung berdasarkan Peruntukan Air Dan Baku Mutu Air

\begin{tabular}{|l|l|l|}
\hline $\begin{array}{l}\text { Stasiun Pemantauan } \\
\text { Kualitas Air }\end{array}$ & $\begin{array}{l}\text { Kelas } \\
\text { Kualitas Air }\end{array}$ & Faktor Pembatas \\
\hline $\begin{array}{l}\text { CG 1, CG 2, CG 3, } \\
\text { CG 4, CG 5, CG 6 }\end{array}$ & B & $\begin{array}{l}\text { BOD, COD, kekeruhan, amoniak, ammonium, nitrat, ortho phospat, fecal } \\
\text { coliform melebihi batas ambang minimum yang diperbolehkan }\end{array}$ \\
\hline $\begin{array}{l}\text { CG 1, CG 2, CG 3, } \\
\text { CG 4, CG 5, CG 6 }\end{array}$ & C & $\begin{array}{l}\text { BOD, COD, kekeruhan, amoniak, ammonium, nitrat, ortho phospat, fecal } \\
\text { coliform melebihi batas ambang minimum yang diperbolehkan }\end{array}$ \\
\hline $\begin{array}{l}\text { CG 1, CG 2, CG 3, } \\
\text { CG 4, CG 5, CG 6 }\end{array}$ & D & $\begin{array}{l}\text { BOD, COD, kekeruhan, amoniak, ammonium, nitrat, ortho phospat, fecal } \\
\text { coliform melebihi batas ambang minimum yang diperbolehkan }\end{array}$ \\
\hline
\end{tabular}

Sumber : Analisa Data (2014)

Kadar BOD, COD, kekeruhan, amoniak, ammonium, nitrat, ortho phospat, dan kadar fecal coliform, telah melebihi baku mutu B, C, D yang diperbolehkan. Hal ini disebabkan karena pada daerah aliran sungai Cisanggarung banyak sekali kegiatan pertanian, perkebunan dan limbah rumah tangga dari pemukiman sehingga kualitas air sungai menjadi tidak baik.

\section{DAFTAR PUSTAKA}

Agus, F,. N. Sinukaban. A. N. Ginting. H. Santoso dan Sutadi. 2007. Bunga Rampai Konservasi Tanah dan Air. Penerbit Pengurus Pusat Masyarakat Konservasi Tanah dan Air Indonesia 2004-2007. Jakarta.

Agustiningsih, D. 2012. Analisis Kualitas Air dan Beban Pencemaran Berdasarkan Penggunaan Lahan di Sungai Blukar Kabupaten Kendal.

Arsyad, S,. 1989. Konservasi Tanah dan Air. IPB Press. Bogor.

Asdak, C., 1995. Hidrologi dan Pengelolaan Daerah Aliran Sungai. Penerbit Gadjah Mada University Press. Yogyakarta.

Athena, S., Hendro. M, Anwar. M, Haryono. 2004. Kandungan Bakteri Total Colidan E. Coli / fecal Coli Air Minum dari Depot Air Minum Isi Ulang di Jakarta, Tangerang dan Bekasi.

Coskun, H.G,. C. Arganei. and G. F Usta. 2008. Analysis of Land Use Change and Urbanization in the Kaculcekmece Water Rasin (Istanbul, Turkey) with Temporal Satelitte Data Using Remote Sensing and GIS Sensors. 8, 72137223 .

De la cruz, A.I,.and P.K. Barten. 2007. Land Use Effects on Streamflow an water Quality in the Northestern United States. CRC Press. Florida-USA.

Deutsch, G.W. and Busby, L.A., 2000. Community-Basid Water Quality Monitoring.

Effendi, H. 2003. Telaah Kualitas Air. Kanisius. Yogyakarta.

Endiriyanti, 2011. Pengaruh Penggunaan Lahan di Daerah Aliran Sungai Cisanggarung Terhadap Kualitas Air.

Ghufrona, R.R., Diviyanti dan Nurroh, S., 2006. Analisis Tutupan Lahan Terhadap Kualitas Air Situ Burung Desa Cikarawang Kabupaten Bogor. Fakultas Kehutanan IPB. Bogor.

I-CLEAN., 2007. pH.http://www.mysaltz.net. Diakses tanggal 26 Maret 2014.

Kusnaedi., 2002. Mengolah Air Gambut dan Air Kotor untuk Air Minum. Penerbit Swadaya. Jakarta.

Logan, T.J., 1990. Sustainable Agriculture and Water Quality. Sustainable Agricultural Systems. Soil and Water Conservation Society. Ankeny, Iowa. 
Peraturan Pemerintah Nomor 38 Tahun 2011 tentang Sungai.

Pennsylvania, L.E., 2006. Land Use and Water Quality.

Prasetyo, S. dan Padmono, J., 1993, Alternatif Pengelolaan Limbah Cair dan Padat RPH. BPPT, Jakarta.

Sofyan, I., 2004. Percentage of Total Impervious Area (PTIA) sebagai Salah Satu Faktor Penting Dalam Perencanaan Tata Ruang DAS.

Sumarmo, LG., 2000. Konsep Usaha Tani Ramah Lingkungan. Puslitbangtan, Bogor.

Supangat, AB. 2008, Pengaruh Berbagai Penggunaan Lahan Terhadap Kualitas Air Sungai Di Kawasan Hutan Pinus Di Gombong, Kebumen, Jawa Tengah.

Supriharyono, 2009. Konservasi Ekosistem Sumberdaya Hayati di Wilayah Pesisir Dan Laut Tropis. Pustaka Pelajar, Yogyakarta.

Suriawiria., Unus. 2003. Air dalam Kehidupan dan Lingkungan yang Sehat. Penerbit Alumni. Bandung.

Sutjianto, R., 2003. Biodeversitas Plankton Sebagai Indikator Kualitas Perairan. FMIPA UNHAS. Makassar.

Sutrisno, T., dan E. Suciastuti. 2002. Teknologi Penyediaan Air Bersih. Cipta Rineka. Jakarta.

Tafangenyasha, C., and T. Dzinomwa. 2005. Land-use Impact o River Water Quality in Lowveld Sand River System in South-East Zimbabwe. Land-use and Water Resource.

Triono, R., 2007. Pengaruh Perubahan Fungsi Lingkungan Terhadap Kelestarian Mata Air Sebagai Sumber Air. Bersih Di Kawasan Cagar Alam Pegunungan Cyclop Distrik Abepura Kota Jayapura. UGM. Yogyakarta.

WHO., 2004. Guidelines For Drinking Water Quality. Third Edition. Volume 1: Recomentadtion. Geneva.

Wiwoho., 2005. Model Identifikasi Daya Tampung Beban Cemaran Sungai dengan Model QUAL2E. Tesis. Universitas Diponegoro. Semarang. 